\title{
WEBSITE QUALITY ANALYSIS OF BALAI BESAR PASCAPANEN BOGOR USING 2QCV3Q MODEL
}

\author{
Rinova Budiman, Arif Imam Suroso, \& Irman Hermadi \\ Department of Management and Bussiness, Institut Pertanian Bogor \\ E-mail: rinova.budiman@gmail.com
}

\begin{abstract}
BB-Pascapanen website is an official website of Balai Besar Pascapanen Bogor whose mission is to be able to integrate information as a research institute producing technology and innovation of agricultural post harvest that supports the realization of food sovereignty and farmers' welfare. Based on the regulation and to accommodate those missions the website has been developed. The purpose of this study is to analyze the quality of the BBPascapanen website through a $2 Q C V 3 Q$ model.This model was chosen because it has a multi-party approach involving three actors in the development of a website, website owner, web developer and user which will make an analysis of website quality management implemented more detail. The results of the analysis show from institution and web developer point of view that the feasibility dimension needs performance improvement. While the other dimensions from user point of view that need to be improved are the dimension of identity (attributes of website uniqueness, Impressum distinctness), content (attribute of information detail and accuracy), services (attribute of correspondence feature), locations (attribute of availability of Link, URL easy to remember, easy searching in website, addresses written in website exists in google map, hotline), and usability (attribute of layout structure, orientation navigation and response, download time).
\end{abstract}

Keywords: information, IPA, quality, websites, 2QCV3Q, BB-Pascapanen Bogor JEL Classification: $M 0, O 3, Y 1$

\begin{abstract}
ABSTRAK
Situs web BB-Pascapanen adalah situs web resmi Balai Besar Pascapanen Bogor yang memiliki misi untuk dapat mengintegrasikan informasi. BB-Pascapanen merupakan lembaga penelitian yang menghasilkan teknologi dan inovasi pasca panen pertanian yang mendukung terwujudnya kedaulatan pangan dan kesejahteraan petani. Berdasarkan peraturan, untuk mengakomodasi misi tersebut, situs web telah dikembangkan. Tujuan dari penelitian ini adalah untuk menganalisis kualitas situs web BB-Pascapanen melalui model 2QCV3Q. Model ini dipilih karena memiliki pendekatan multi-partai yang melibatkan tiga aktor dalam pengembangan situs web, yaitu pemilik situs web, pengembang web dan pengguna. penggunaka merupakan pihak yang akan membuat analisis manajemen kualitas situs web diimplementasikan lebih detail. Hasil analisis menunjukkan dari sudut pandang institusi dan pengembang web bahwa dimensi kelayakan membutuhkan peningkatan kinerja. Sedangkan dimensi lain dari sudut pandang pengguna yang perlu ditingkatkan adalah dimensi identitas (atribut keunikan situs web, perbedaan Impressum), konten (atribut detail dan akurasi informasi), layanan (atribut fitur korespondensi), lokasi (atribut ketersediaan Tautan, URL mudah diingat, pencarian mudah di situs web, alamat yang ditulis dalam situs web ada di google map, hotline), dan kegunaan (atribut struktur tata letak, navigasi dan respons orientasi, waktu pengunduhan).
\end{abstract}

Kata kunci: informasi, IPA, kualitas, situs web, 2QCV3Q, BB-Pascapanen Bogor Klasifikasi JEL: MO, O3, Yl 


\section{INTRODUCTION}

At the present time, the need for information cannot be ruled out, so information technology needs to be continuously developed. E-Government as one of the technological implications in governmental administration should implement the trend. Delivering information to the public must be better supported by technology. The Indonesian government, through its policy, encourages all public institutions to implement EGovernment, one of which is the development of agency websites. As a public institution, Balai Besar Pascapanen Bogor carries out public information services through the official website http://pascapanen.litbang.pertanian.go.id, whose mission is to be able to integrate information as a research institute producing technology and innovation of agricultural postharvest that supports the realization of food sovereignty and farmers welfare. Based on the regulation and to accommodate those missions the website has been developed.

BB Pascapanen website (http://pascapanen.litbang.pertanian.go.id) is an official website of BB-Pascapanen Bogor whose mission is to be able to integrate information as a research institute producing technology and postharvest agricultural innovation that supports the realization of food sovereignty and farmers' welfare. The level of quality of the website has never been measured to determine the success rate of implementing the mission. To find out how far the quality of website services can be received by users, an assessment is needed to measure the quality and effectiveness of a website to be well received by users. In addition, this assessment can improve the quality of BB-Pascapanen websites in providing public information service. This research is a type of research with a new approach model, namely the $2 Q C V 3 Q$ model which is still very rarely used in similar research regarding website quality management. The new $2 Q C V 3 Q$ model was tested on tourism website research, and only in this study was used for the e-government context.

An organization with a website that is difficult to use can create a bad reputation on the internet and weaken the position of the organization (Barnes \& Vidgen, 2002). Therefore, it is important that the organization can assess the quality of the website whether it has fulfilled what is perceived by users. According to research conducted by Mich et al. (2003), namely the $2 Q C V 3 Q$ Model for evaluating the quality of the website from the perspective of the owner, the developer, and user which has seven quality dimensions. The $2 Q C V 3 Q$ model enables a multi-stakeholder approach because it considers website sponsors, users, designers and all involved in implementation (Mich et al., 2003).

Tsigereda W. Mebrate (2010), reviewed several types of models to improve the website. Among them are Web-QEM, 2QCV3Q, MiLE, and MINERVA. All models for approving websites are sourced from ISO-9126. The results of the research conducted are a new framework for approving websites. The framework consists of high-level quality factors and sub quality factors and is named the WEB-USE method. The high-quality quality proposed is Content, Usability, Reliability, Efficiency, sub-quality factors.

Kamanlıoğlu and Emiroğlu (2009) is the first study to discuss the website features of companies in the Turkish fisheries sector. The purpose of this study is to discuss the level of participation of web companies with websites and to determine the differences between web companies in terms of design and content features through qualitative qualifications. The $2 Q C V 3 Q$ model is used to improve the website. The results of the statistical analysis show 


\section{Rinova Budiman \\ Arif Imam Suroso \\ Irman Hermadi}

that web processing and processing companies of aquaculture are more successful than aquaculture and fisheries companies.

\section{LITERATURE REVIEW}

\section{The $2 Q C V 3 Q$ Web sites Analysis and Evaluation Model}

The $2 Q C V 3 Q$ model (in Latin $V$ pronounced $U$ ) is the name obtained from the Ciceronian loci initials that use the principles of classical rhetoric. The $2 Q C V 3 Q$ model permits a multistakeholder approach that considers the viewpoints of all involved. Developing a website with a specific purpose and specific intention still involved more people with different knowledge and skill, and therefore contribute also different priorities and attitudes. The model's first version ( $2 Q C V 2 Q)$ focuses on on-site evaluation following six main dimensions, corresponding to six loci. The second version, extended for site design, includes the seventh locus included in classical rhetoric lists. This lets us consider especially important elements for Web site development projects and of course analyzing the quality of websites cannot be separated from the important element in its development.

The following are three main roles in making and developing websites according to the 2QCV3Q Model according to Mich et al. (2003).

a. Site owner, which shows the goals of the website such as sponsors, promoters or clients.

b. Users, focusing on the needs and expectations of users.

c. The developer and nontechnical technician focuses on the part in developing and also managing websites both software, hardware, databases, networks and more.

Dimensions in the 2QCV3Q Model in Cicero Locus according to Mich et al. (2003) namely as follows:

a. QVIS (identity): Logo, URL, Color, Design,

b. QVID (content): Accuracy of Information, content validity, Timely (up-to-date), Easy to understand, Details, Format as expected

c. CVR (services): Guaranteed privacy security, correspondence features, Ease of providing feedback, Website free of error and trusted

d. VBI (location): Website is easy to find. There are contacts/links for other sources, URLS are easy to remember, Easy to search in the website. Addresses can be found in google map, Website found on popular social media, (reachability aspects), contact availability

e. QVANDO (management): Modernization of technology, the novelty of information, innovation, evaluation, tools used, software

f. QVOMODO (usability): Easy of operating the web, easy to understand the web, attractive appearance, web consistency, easy navigation in the web, language can be understood, can be accessed on various devices, user disability support features, structured display, clear orientation, accurate navigation buttons, fast accessresponse-download time.

g. QVIBUS AVXILIIS (feasibility): Time, Financial, human resources, Support infrastructure facilities for web development (and also maintenance). 


\section{Importance-Performance Analysis}

Importance-Performance Analysis (IPA) is a method of measuring the level of conformity to find out how much the customer is satisfied with the company's performance and how much the service provider understands what the customer wants for the services they provide (Simamora, 2004). This method also has the main information function related to service factors that affect user satisfaction and the factors that need to be improved to fulfill user satisfaction. This method has been widely used to measure the quality of the website (Nistantya et al., 2015). Related to this research the IPA method is used to measure the performance of BB-Pascapanen websites at the point of view of the user.

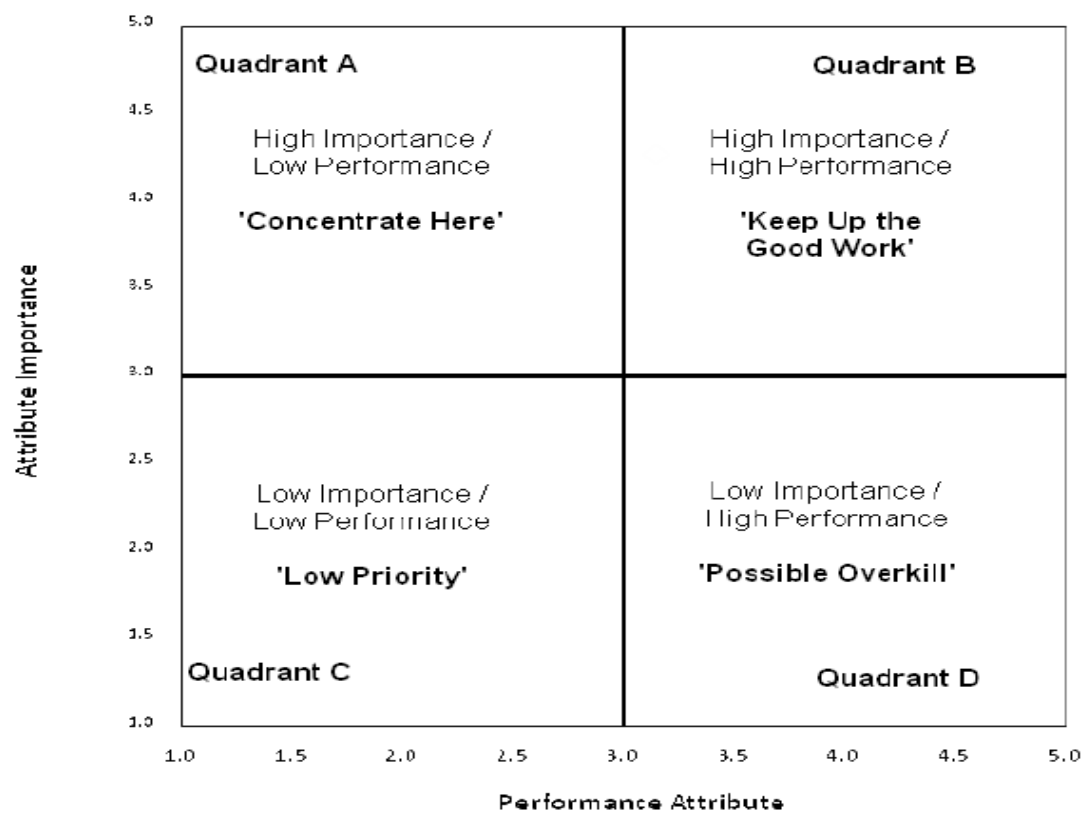

Figure 1.

Importance-Performance Analysis

IPA technique has a matrix which is a building that is divided into four sections which are bounded by two lines that intersect perpendicular to the points $X$ and $Y$. Point $X$ is the average (mean) score of the level of performance and point $Y$ is the average score of the level of importance or expectation of all attributes that affect satisfaction. The IPA matrix is shown in Figure 1. The interpretations of the four quadrants are as follows:

1. Quadrant 1 (Top priority)

This is an area that contains factors that are considered important by Users, but in reality, these factors are not in line with customer expectations. The variables included in this quadrant must be increased.

2. Quadrant 2 (Maintain achievement)

In this awareness, there are factors that are considered important and expected as a factor supporting user satisfaction so that the company is obliged to maintain these performance achievements.

3. Quadrant 3 (Low Priority)

The level of importance and level of satisfaction of some of the attributes contained in this quadrant is relatively low, so it needs to be considered and managed seriously by the company because dissatisfaction with user responses generally starts from this condition. 


\section{Rinova Budiman \\ Arif Imam Suroso \\ Irman Hermadi}

4. Fourth quadrant (Excess)

This quadrant is an excessive area where expectations are low but the perception is so high. This area is not a priority area that must be addressed by an organization or company.

\section{Research Concept}

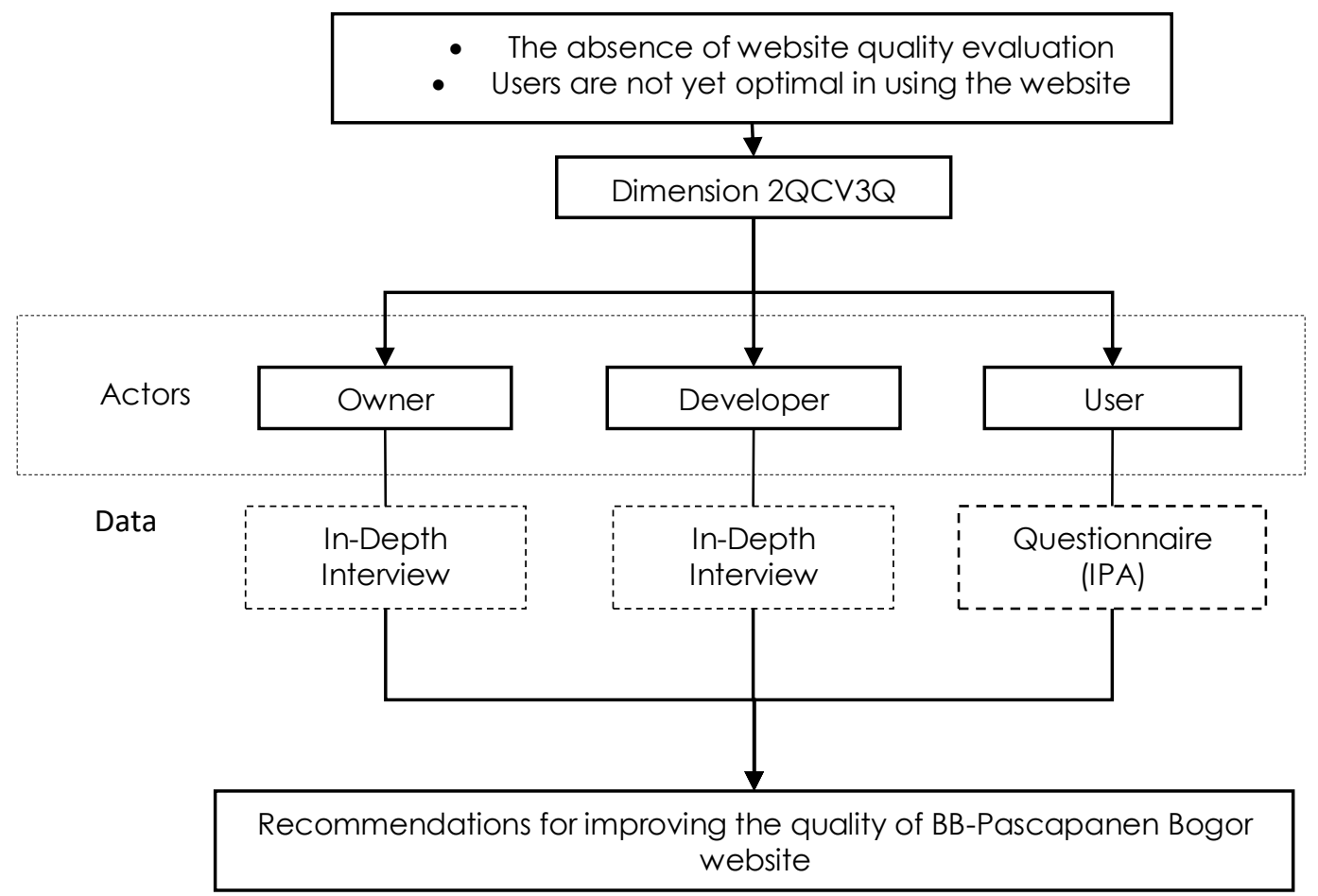

Figure 2.

Research Concept

\section{METHODS}

Primary data in this study are data obtained from direct observation, depth interviews and questionnaires aimed at the owner, developer, and user of the BB-Pascapanen Bogor website. Depth interviews given to agencies and developers are open questions so that respondents do not have the limits to give answers. The questionnaire given to the user contains closed questions (structured) where an answer is a number of choices determined by the researcher. Making questionnaires in accordance with the dimensions to be studied modified from the research questionnaire (Fitrahdini et al., 2010). Closed questions are questions that are made in such a way that respondents are limited to giving answers to certain alternative answers. Answer questions are made on a scale of 1-5 for each of the indicators of interest and performance in the IPA method, which is "strongly disagree", "disagree", "neutral", "agree" and "strongly agree".

The research results found cannot be digitalized for the population of examples and only apply to examples or respondents used in the research. Any respondent criteria as users that are surrounded by it: 
a. Once accessed the Bogor Post-harvest website.

b. Above 18 years old. Sumarwan et al. (2015) explains that age differences will also lead to differences in mindset and response to anything seen and criticized.

With these criteria, anyone who has ever accessed the Bogor BB-Postharvest website and is over 18 years of age, through data from the Bogor Post-Graduate Office and distributed using Google Form during the study period, will be made a respondent. During the study period, there were 88 respondents.

As a source for website user respondents, BB-Pascapanen Bogor provides information to the author regarding visitor data or access to the BB-Pascapanen website for the past year containing the visitor's name along with the visitor's email address or Facebook link. The researcher then re-sorted the prospective respondents based on the age above 18 years with the reasons previously described. Until finally the writer distributed the questionnaire through email and Facebook messenger that had been registered. Based on the results of a questionnaire that was willing to be filled out by respondents during one month of research, this is what determines the number of respondents.

Respondents as owners (BB-Postharvest institutions) with the criteria of knowing and being responsible for managing the BB-Pascapanen Bogor website sampling using a purposive sampling method through in-depth interview techniques. As an expert speaker, Ms. Lina Marlina SS. M. Sc as Head of Agricultural Product Utilization Section and Mr. Erwan Agustian Apriyansyah as Public Relations Officer.

Respondents as Developers who have criteria for mastering technical knowledge about websites ranging from development to management and management are carried out the same sampling methods and techniques as those of actor owners with expert resource persons Mr. Ferdianto Tejo Rahmad as IT staff of the Bogor Postharvest BB.

\section{RESULTS AND DISCUSSION \\ Dimension Analysis of the 2QCV3Q Model Based on Actors Point of view Owner}

Based on the model developed by Mich et al. (2003) dimensions of the $2 Q C V 3 Q$ model submitted to the owner according to their role as an actor, namely the dimensions of identity, content, service, management, and feasibility. From the institution's perspective, the identity dimension such as brand or name, agency domain is important, but because it belongs to the government, the name, logo, and domain are determined by the ministry of agriculture so that the identity should be easy for user, namely Farmers' Groups, SMEs, students, and researchers in accessing the website.

In the dimensions of the content, BB-Pascapanen agencies informing what will is and has been done by agencies such as research of agricultural products and technology, information on an auction of laboratory equipment which is claimed to be one of the favorites sought after information through the website. Agency scheduled updates on reports, news and activity information regularly, if there is no activity, then the technology results article will be displayed instead. Dimensions of service, BB-Pascapanen guarantees the availability of information technology that is easily applied and delivered in easy language by packaging it in the form of infographics, minimizing the use of tables and 


\section{Rinova Budiman \\ Arif Imam Suroso \\ Irman Hermadi}

numbers and focusing on the benefits, uses and ways of appropriate implementing, effective and efficient technology.

To guarantee that the agency provides the opportunity to interact directly with the social media approach, in which correspondence using the comment feature is responded directly. Management dimensions are associated with maintenance, technology modernization, innovation, evaluation, and tools used. The appearance of the website follows the trend after evaluation, technology innovation is confirmed to be appropriate enough to run well on the latest devices, the new platform even claims that the application is mobile friendly. The feasibility dimension contains aspects of resources owned by agencies such as time, finances and human resources. Agencies are able to develop websites, but there are limited funds to develop infrastructure to PPID (Information and Documentation Management Official) specific websites, which better should have its own infrastructure and website due to distinctive information content to separate different users in searching for specific information. The human resources aspect is so far sufficient.

\section{Web Developer}

The dimensions addressed to the web developer are location, management, usability, and feasibility. This dimension in researching web developers is also used in research Kamanlıoğlu and Emiroğlu (2009) which explores the website features of companies in the Turkish fisheries sector. The purpose of this study is to examine the level of the company's web presence by evaluating websites and to determine the differences between web companies in terms of design and content features through a qualitative approach.

From the developer point of view, the location dimensions are reachability, whether the BBPascapanen website can be accessed by the user. The website address http://pascapanen.litbang.pertanian.go.id is an official request from the Ministry of Agriculture. The URL is considered to have represented the agency because it is easily remembered by the user. The popularity of websites on search engines is after the ministry main website. The internal search engine features are available and work well, and information architecture has a good design, the content hierarchy is clear.

From the management dimension, this website applies the Hierarchical Roles system, there are administrators, editors, and contributors in writing content. The website is claimed to be up to date. Schedule posts and CMS (Content Management System) can be done every time because of an admin system that allows us to update anytime, anywhere, particularly the news content. From the usability dimension, the BB-Pascapanen website is quite easy to use, because it maximizes the display of information needed in the form of content and news and the keywords. Developers make professional website views by using the tagline "Science, Innovation, Network". The main layout appearance is based on science and the network and matches its tagline. The website can be browsed by users without technical knowledge about the website. Navigation and content index makes it easy in searching, there is a menu, navigation, and index sitemap and the website can be accessed using any device, already mobile friendly and there is an application on the Android platform.

From dimension feasibility, financial resources are sufficient, but developers still need to add at least three people to support programming, design, and servers, so the important attribute 
of human resources still insufficient. Infrastructure still requires an additional hard drive to back up the database.

\section{User}

Dimensions that refers to users are the dimension of identity, content, service, location, and usability. The respondents in this study were 64 of BB-Pascapanen website users who frequently visited the website and ever done direct contact to the agency via email or by phone. Respondents were dominated by women, aged 18-27, master-doctoral education, and the work of civil servants. The questionnaire given to the user contains closed (structured) questions where the answers are in the form of several choices determined by the researcher. The compiling questionnaire is adjusted to the dimensions to be studied and also modified (Fitrahdini et al., 2010). The results of the questionnaire distributed to user respondents were processed by the IPA (Importance-Performance Analysis) method. The level of conformity is the result of a comparison of perception or performance scores with a score of importance or expectation (Supranto, 2011). The results of the conformity level analysis are presented in Table 1.

Based on Table 1, there are no attributes that show performance below $70 \%$. There are 5 attributes with a performance level of $70-79 \%$, and the most attribute shows the level of suitability at $80-89 \%$. The suitability level of $90-99 \%$ has 9 attributes. Then only two attributes that indicate the level of conformity is more than $100 \%$ or can be said the performance exceeds what is expected by the user. Whereas other variables indicate the level of conformity is below $100 \%$ or its performance is still below the expectations of the user. Although in general, it is not in accordance with the expectations of users the satisfaction value is above $70 \%$.

Attributes in the BB-Pascapanen Bogor website that need attention and improvement are analyzed using a Cartesian diagram. In Cartesian diagram can be seen attributes that need to be improved, maintained or even reduced the level of the performance because it is considered too excessive in its implementation. The results of the Cartesian diagram analysis are available in Diagram 1.

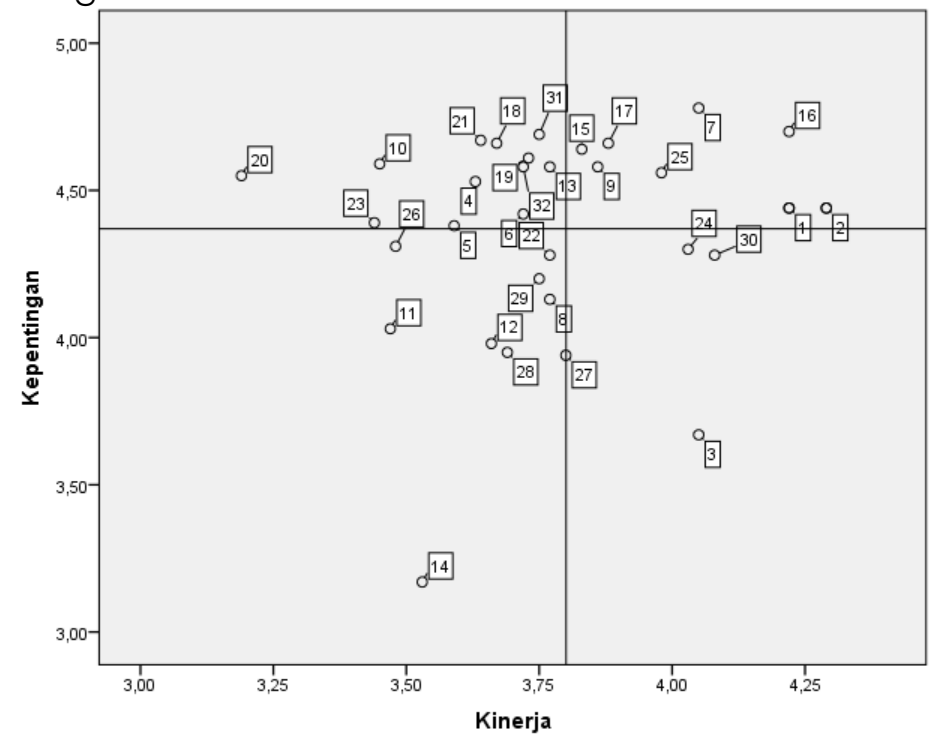

Diagram 1.

Cartesian Diagram 


\section{Rinova Budiman \\ Arif Imam Suroso \\ Irman Hermadi}

The attributes in quadrant $A$ are attributes that are considered important by the user, but the owner has not been able to realize it according to the expectations of the user. Attributes in quadrant $A$ are the main priority for the improvement of implementation and quality, as for those included in quadrant $A$ based on $2 Q C V 3 Q$ dimensions as follows:

a. Identity

Users need a more attractive design to be a priority. In addition, Impressum such as "Contact Us", "Term \& Condition". "Organization/Company Info Pages" on the website page must be clearer or displayed properly.

b. Content

Priority improvements in the dimensions of content are accuracy and detailed information. This is indicated by the number of users who feel dissatisfied with the information needed through the website, which requires more interaction and communication with agencies (information providers). The research entitled BPK RI Pusdiklat Website Quality Evaluation Using the Webqual Method with results that show that to increase user satisfaction and loyalty for services provided by maintaining the performance consistency of some attributes of information that have the biggest contribution to the quality of website services (Wicaksono \& Susanto, 2013).

c. Service

The attributes that need to be fixed in the service dimension are the correspondence feature. This is related to the dimensions of content that the user believes is not optimal yet in delivering accurate and detailed information.

d. Location

The most widely corrected attributes are in the dimension of location, this is in line with the importance level of user interest which shows that this dimension is the most important. Attributes that need to be corrected are the information source link, the website address which is still difficult to remember, the ease of searching in the internal website itself such as availability of internal search engines that work optimally, google map services for physical location search, and availability of hotline services.

e. Usability

Attributes that need to be corrected in the usability dimension are the appearance structure, website orientation, and accurate navigation buttons. Besides, those other attributes are the speed of download time, response, and access.

In general, from previous research studies, some of which can be used as references in the research that will be carried out related to the quality analysis of Bogor BB-Postharvest websites are the $2 \mathrm{QCV} 3 \mathrm{Q}$ models that will be used. This model involves three actors in analyzing the quality of the website, namely the Owner or organization (Companies, associations, individuals), Users (users) and Developers (programmers, analysts, content developers). In addition, the development in this study is to use the Important Performance Analysis approach to measure the level of expectations and performance of the BBPascapanen website in the user's perspective. This refers to a previous study which analyzed the quality of e-government services with the IPA method (Fatmala et al., 2018; Saputra, 2018). The Importance Performance Analysis method has the main function of displaying information related to service factors that affect user satisfaction and factors that need to be improved because the current situation is not satisfactory according to the user. This method has been widely used to measure the quality of a website (Nistantya et al., 2015). 
Table 1.

Level of comformity of performance and importance

\begin{tabular}{|c|c|c|c|c|c|}
\hline \multirow[b]{2}{*}{$\mathrm{Nb}$} & \multirow[b]{2}{*}{ Attributes } & \multirow[b]{2}{*}{ Code } & \multicolumn{2}{|c|}{ Measuring scale } & \multirow{2}{*}{$\begin{array}{l}\text { Level of } \\
\text { Conformity } \\
(\%)\end{array}$} \\
\hline & & & Importance & Performance & \\
\hline 1 & Logo describes the organization & ID01 & 4,44 & 4,22 & 95 \\
\hline 2 & Domain name reflects the institution & ID02 & 4,44 & 4,29 & 97 \\
\hline 3 & $\begin{array}{l}\text { Colors on the website represent the } \\
\text { institution }\end{array}$ & ID03 & 3,67 & 4,05 & 110 \\
\hline 4 & $\begin{array}{l}\text { Design of website unique and } \\
\text { represents the institution }\end{array}$ & ID04 & 4,53 & 3,63 & 80 \\
\hline 5 & Impressum on the website is clear & ID05 & 4,38 & 3,59 & 82 \\
\hline 6 & Accuracy of information & $\mathrm{COOl}$ & 4,42 & 3,72 & 84 \\
\hline 7 & Validity of information & $\mathrm{CO} 2$ & 4,78 & 4,05 & 85 \\
\hline 8 & Information is up to date & $\mathrm{CO03}$ & 4,13 & 3,77 & 91 \\
\hline 9 & Information is understandable & $\mathrm{COO4}$ & 4,58 & 3,86 & 84 \\
\hline 10 & Information Detail & CO05 & 4,59 & 3,45 & 75 \\
\hline 11 & $\begin{array}{l}\text { Information in the form of users } \\
\text { expectation }\end{array}$ & $\mathrm{CO06}$ & 4,03 & 3,47 & 86 \\
\hline 12 & Privacy guarantee & SEOI & 3,98 & 3,66 & 92 \\
\hline 13 & Correspondence feature & SE02 & 4,58 & 3,77 & 82 \\
\hline 14 & The user can give feedback & SEO3 & 3,17 & 3,53 & 111 \\
\hline 15 & Website is trusted & SEO4 & 4,64 & 3,83 & 82 \\
\hline 16 & Free of error & SEO6 & 4,70 & 4,22 & 90 \\
\hline 17 & Web address easily found & LOO1 & 4,66 & 3,88 & 83 \\
\hline 18 & Availability of other source and links & LO02 & 4,66 & 3,67 & 79 \\
\hline 19 & Web address easily remembered & LOO3 & 4,61 & 3,73 & 81 \\
\hline 20 & Ease of searching in the web & LOO4 & 4,55 & 3,19 & 70 \\
\hline 21 & $\begin{array}{l}\text { The address listed on the website for } \\
\text { certain locations can be found on } \\
\text { Google Map }\end{array}$ & LO05 & 4,67 & 3,64 & 78 \\
\hline 22 & $\begin{array}{l}\text { The website can be found in popular } \\
\text { social media }\end{array}$ & LO06 & 4,28 & 3,77 & 88 \\
\hline 23 & Website includes hotline & LO07 & 4,39 & 3,44 & 78 \\
\hline 24 & Website easy to operate & USO1 & 4,30 & 4,03 & 94 \\
\hline 25 & Website clear and understandable & USO2 & 4,56 & 3,98 & 87 \\
\hline 26 & $\begin{array}{l}\text { Websiteattractive, and comfortable to } \\
\text { use }\end{array}$ & USO3 & 4,31 & 3,48 & 81 \\
\hline 27 & Professional and consistent & USO4 & 3,94 & 3,80 & 96 \\
\hline 28 & Easy to navigate & USO5 & 3,95 & 3,69 & 93 \\
\hline 29 & $\begin{array}{l}\text { Language and terminology } \\
\text { understandable }\end{array}$ & USO6 & 4,20 & 3,75 & 89 \\
\hline 30 & Accessible with any device & USO7 & 4,28 & 4,08 & 95 \\
\hline 31 & $\begin{array}{l}\text { Structured of layout, clear orientation, } \\
\text { accurate navigation button }\end{array}$ & US09 & 4,69 & 3,75 & 80 \\
\hline 32 & $\begin{array}{l}\text { Fast access, response and download } \\
\text { time }\end{array}$ & US10 & 4,58 & 3,72 & 81 \\
\hline
\end{tabular}

Based on the $2 Q C V 3 Q$ dimension evaluation, some attributes need to be corrected from each actor, a recommendation that can be implemented, among others.

1. Presents a live chat feature to accommodate actual and continuous communication between users while browsing websites. Any questions, complaints, requests, and 


\section{Rinova Budiman \\ Arif Imam Suroso \\ Irman Hermadi}

other interactions by the user must be responded quickly by the service provider (Indrajit, 2012).

2. Then enclose the detailed and clear address and contact. Papadomichelaki and Mentzas (2011) in the case of interaction between the community and service providers to solve problems, the availability of communication channels (telephone, e-mail, fax, suggestion box, etc.) is very important.

3. Considering the importance of the database, immediately data back-up management should be conducted with incremental back-up due to limited resources on the feasibility dimension.

4. Increased information related to postharvest technology on the main menu. In a website must be considered the customer value, one of which is presenting interesting content (content that has commercial value, maintained quality, always up-to-date and relevant) (Indrajit, 2012). Besides that, focusing on thematic content prevents distraction and stress for the user who needs information in a hurry or who are not native language speaker.

5. Information on popular social media should always include a link to the BBPascapanen website.

6. Increase human resources for website management, especially regarding technical matters such as programming, web design, and server maintenance.

\section{CONCLUSION}

Based on the $2 Q C V 3 Q$ analysis result concluded that from the owner and the developer point of view, the quality of the BB-Pascapanen Bogor need to be considered and improved its performance, namely feasibility dimension, attributes of financial resources to develop PPID website and supporting infrastructure, (PPID facility should be separated by creating a specific website), to provide large capacity hard drives to back up databases and attribute of human resources to manage website. In the conformity analysis through ImportancePerformance Analysis method (IPA) between the level of importance and performance from the user's point of view on the website, shows that most of the $2 Q C V 3 Q$ attributes are less than $100 \%$. These results indicate that the performance of the website, in general, has not satisfied the users. Based on the Cartesian diagram (Importance-Performance Analysis), it is known that the priority for improving the BB-Pascapanen Bogor website from the user's perception is in quadrant $A$, which is the attribute of the unique website design, clear impresses, accuracy and detailed information, correspondence features, link sources, easy to remember the URLs, ease of searching on the website, the address listed on the google map, hotline, structure, orientation and navigation buttons, access, response and download time. This research is limited to seven variables in the $2 Q C V 3 Q$ method, namely identity, content, service, location, management, usability and feasibility which will be aimed at three parties, namely the BB-Pascapanen Bogor, website developer, and website users.Respondents from the agency and developer were chosen with the criteria to truly understand and be responsible for managing the website. Whereas for the respondents from the website users is limited to users who have accessed the website and have made direct contact to the BB-Pascapanen Bogor through various media listed on the website (email, telephone, and agency address). The suggestion for next research is different data collection methods from users (users) and can be done using other data processing methods with more specific respondents, and more samples and longer time frames. 


\section{REFERENCES}

Barnes, S. J., and R. Vidgen. 2002. An Integrative Approach To The Assesment Of ECommerce Quality. Journal Of Electronic Commerce Research. 3(3):1 14-127.

Fatmala, W. S., Supranto, and A. Rachmadi. 2018. Analisis kualitas layanan website ecommerce berrybenka terhadap kepuasan pengunjung menggunakan metode webqual 4.0 dan importance performance analysis (IPA). Jurnal Pengembangan Teknologi Informasi dan Ilmu Komputer. 2(1): 175-183.

Fitrahdini, U., Sumarwan, and R. Nurmalina. 2010. Analisis Persepsi Konsumen Terhadap Ekuitas Merek Produk Es Krim. Jurnal Ilmu Keluarga dan Konsumen. 3(1):74-81.

Indrajit, R. E. 2012. Kriteria Website Desain Efektif. [internet]. [downloaded on Juli 21th 2018]. Available on: http://www.academia.edu/14332977/Kriteria_Desain_Website_Efektif.

Kamanlıoğlu, E., and D. Emiroğlu. 2009. Qualitative evaluation of web sites of firms in turkish fishery sector. Journal of fisheries \& aquatic sciences. 26(1): 65-72.

Mich, L., M. Franch., and G. Cilione. 2003. The 2QCV3Q Quality Model for The Analysis of Web Site Requirements. Journal of Web Engineering. 2(1\&2): 105-127.

Nistantya, G., E. Darwiyanto., and H. Hidayati. 2015. Evaluasi Kualitas Website Digital Library Telkom University Menggunakan Metode Webqual 4.0 dan Importance Performance Analysis. Jurnal Eproc Telkom.

Papadomichelaki, X. and G. Mentzas. 2011. E-govqual a multiple item scale for assessing egovernment service quality. Government Information Quarterly. 29 (2011): 98-109.

Saputra, R. A., Supranto, and A. Rachmadi. 2018. Penilaian kualitas layanan e-government dengan pendekatan dimensi e-govqual dan importance performance analysis (IPA) (studi kasus pada Pemerintah Provinsi Nusa Tenggara Barat). Jurnal Pengembangan Teknologi Informasi dan Ilmu Komputer. 2(5) : 1794-1802.

Simamora. 2004. Panduan Riset Perilaku Konsumen. PT. Gramedia Pustaka Utama. Jakarta, Indonesia.

Supranto, J. 2011 . Pengukuran Tingkat Kepuasan Pelanggan Untuk Menaikkan Pangsa Pasar. 2nd Ed. (ID): Rineka Cipta. Jakarta.

Tsigereda, W. M. 2010. A framework for evaluating academic website quality from students' perspectives. Thesis. Netherland (ND): University of Technology.

Wicaksono, B, L., and A. Susanto. 2013. Evaluasi kualitas layanan website pusdiklat bpkri menggunakan metode web qual modifikasian dan importance performance analysis. Jurnal Nasional Teknik Elektro dan Teknologi Informasi (JNTETI). 2(2). 